\title{
Perceptions of Micro, Small, and Medium Enterprises as Taxpayers Towards Tax Incentives
}

\author{
I Nyoman Darmayasa $^{1}$, Ni Komang Asri ${ }^{2}$ \\ \{nyomandarmayasa@pnb.ac.id ${ }^{1}$, asri.komang123@gmail.com² \\ Accounting Department, Politeknik Negeri Bali, Badung, 80364, Indonesia
}

\begin{abstract}
This study aimed to reveal the perception of micro, small, and medium enterprises (MSMEs) as taxpayers towards tax incentives. This study employed a qualitative method with an interpretive approach. We interviewed three key informants as representatives of MSMEs. The interview manuscript was validated with observations and documentation. The results showed that the micro and small enterprise taxpayers rarely utilized the incentives for some reason. Their perception was only to pay the tax in small amounts because their revenue decreased drastically due to the pandemic. The medium enterprise taxpayers hired tax consultants due to complicated tax administration. Their perception was to pay the tax based on the tax consultants' advice, and they appreciated any incentives given. This study has a practical contribution to tax authorities. It is expected that tax authorities will evaluate the following tax incentives by making tax incentives and tax administration less complicated.
\end{abstract}

Keywords: Complicated tax administration; perceptions of MSMEs taxpayers; tax compliance; tax incentive

\section{Introduction}

The Covid-19 pandemic has hit Indonesia since the beginning of 2020, and cases continue to increase, causing a decline in the Indonesian economy. The Covid-19 pandemic has led to the termination of employment, a decrease in the purchasing managers' index (PMI) of Indonesian manufacturers, a decrease in imports, and inflation [1]. The Covid-19 pandemic has also slowed down the micro, small and medium enterprises (MSMEs) economy. MSMEs experience a slowdown in product absorption, availability of raw materials, and distribution processes [2]. In addition, if the government cannot manage the Covid-19 pandemic well, it will cause more problems on the sustainability of MSMEs, including bankruptcy [3]. Therefore, the participation of many parties, including the government, is needed to strengthen the MSMEs economy.

The Covid-19 pandemic has lowered GDP statistics for the MSMEs sector. Most MSMEs are forced to close because they are unable to meet operational costs. The Covid-19 pandemic had a significant impact on decreasing people's income and purchasing power [4]. It also has led to a decline in exports and imports due to declining demand [5]. Decreased income causes business shifts, termination of employment, and difficulty finding a job [6]. The government is trying to implement a policy to support the people by providing fiscal incentives. Fiscal 
incentives for MSMEs are regulated in the Regulation of Minister of Finance No. 9/PMK.03/2021. Taxes usually collected at $0.5 \%$ of the gross turnover are borne by the government [7]. Fiscal incentives for businesses affected by the Covid-19 pandemic have been effective since April 2020 through the Regulation of Minister of Finance No.44/PMK.03/2020. Fiscal incentives borne by the government provide convenience in calculating, depositing, and reporting income tax payable. The purpose of providing fiscal incentives, especially for MSMEs, is to reduce difficulties in meeting MSME operational costs and maintain the national economy [8].

The convenience provided by the government through fiscal incentives for MSMEs has not been fully utilized. Until the end of 2020, only IDR 16.2 trillion (13.34\%) of the fiscal incentives from the government's budget (IDR 120.61 trillion) were used [9]. The percentage was far below expectation. Some factors leading to this low use of the fiscal incentives could be the government's lack of socialization and uncertainty about giving fiscal incentives during the pandemic [10]. The low utilization of MSMEs fiscal incentives during the Covid-19 pandemic occurred because taxpayers did not understand the requirements and the registration process to obtain fiscal incentives [3]. The unused fiscal incentives should be allocated for the community's health insurance and economy [11]. The sub-optimal use of fiscal incentives will cause the government policies to have no significant impact. Fiscal incentive funds could help the national economy [12]. MSMEs as economic drivers are expected to take advantage of fiscal incentives and help grow the economy. Taxpayers' perception of fiscal policies also caused the low use of fiscal incentives by MSMEs during the pandemic. Tax perceptions are simultaneously related to tax knowledge and fiscal incentives [13]. In addition, perceptions of fiscal incentives influence MSMEs tax compliance [14]. The compliance and trust level in taxes and tax authorities also create tax compliance [15]. Therefore, the taxpayers' perception factor shows the taxpayer compliance level to policies and impacts the implementation of fiscal incentive policies. Losses experienced by MSMEs affect the low fiscal implementation, resulting in prioritizing operational cash flow [16].

Previously, MSMEs had a strong role in the country's economy. MSMEs absorb a larger number of workers to reduce unemployment and poverty [17]. In 2018, MSMEs absorbed $99 \%$ of the total number of business actors in Indonesia [18]. MSMEs contribution to the Gross Domestic Product (GDP) increased per year-from $61.07 \%$ in 2018 to $65 \%$ in 2019 [19]. Bali is one of the provinces with high growth of MSMEs in Indonesia. Badung Regency is one area in Bali having many MSMEs. Tax revenue from North Badung Regency was recorded at IDR 103.5 billion in 2020 . This number increased by $19.12 \%$ from 2019 , which was IDR 86.9 billion [20]. Thus, this study would discuss the low use of fiscal incentives for MSMEs in Indonesia by understanding the perceptions of taxpayers, especially MSMEs taxpayers in Bali.

\section{Methodology}

This study employed a qualitative method with an interpretive approach and focused on analyzing the perception of taxpayers on fiscal incentives for MSMEs. This study was conducted with interviews to reveal the perspectives of the taxpayers on taxes and fiscal incentives. We expected to obtain factual and actual data and information. The study took place in North Kuta District, Badung Regency, Bali. This location was chosen because it was close to our residence, affecting the closeness of the informants to us, so we hoped to build trust with the informants, and they could share the data we needed without any hesitation. 
Data were collected through observations, interviews, and documentation. The expected results were responses from MSMEs as taxpayers in North Kuta District, Badung Regency, Bali. Primary data collection was done face-to-face to avoid information bias. The names of the informants and the time of the interviews were done are presented in Table 1 below:

Table 1. Names of Informants

\begin{tabular}{cclc}
\hline No & Name & \multicolumn{1}{c}{ Role } & Time of interview \\
\hline 1 & Mr. Ketut & $\begin{array}{l}\text { MSME taxpayer, having a medium } \\
\text { enterprise and was engaged in } \\
\text { cooperatives }\end{array}$ & June $1^{\text {st }}, 2021$ \\
2 & Mr. Made & $\begin{array}{l}\text { MSME taxpayer, having a small } \\
\text { enterprise and was engaged in sales } \\
\text { of goods }\end{array}$ & June $4^{\text {th }}, 2021$ \\
3 & Mrs. Putu & $\begin{array}{l}\text { MSME taxpayer, having a micro- } \\
\text { enterprise and was engaged in the } \\
\text { manufacture }\end{array}$ & June $6^{\text {th }}, 2021$ \\
\hline
\end{tabular}

The study employed a descriptive analysis to explain the relationship among events to solve the problem. The data analysis process began with data collection through literature review, observations, interviews, and documentation. At the initial stage, we conducted a literature review to synthesize theories from various perspectives. Then, we made observations to determine the research object physically. Observations were carried out digitally through a website that connected us with the informants. We also made observations by directly visiting the study site. The next process was in-depth unstructured interviews with key informants. Interviews provided an opportunity for informants to express their opinions. Interview results were recorded manuscripts as part of the research documentation to support evidence in the study.

The validity of the data obtained was then tested through triangulation techniques. A discussion was carried out throughout the data collection. If invalid initial data were found, we would replace the data with the following data to test the data validity. Data analysis was carried out by elaborating the perceptions of MSME taxpayers according to themes. The first research theme was the perspectives of taxpayers on taxes and tax compliance. The next theme was the perspectives of taxpayers on fiscal incentives during the Covid-19 pandemic. We explored the reasons behind the willingness and reluctance of informants to utilize fiscal incentives.

\section{Results and Discussion}

\subsection{Tax is a Legal Burden}

People believing that taxes are very important for the country will be willing to pay taxes at any rate, even if the payment process is rather complicated. In Indonesia, taxes are still seen as a burden for individuals and entrepreneurs [23]. In addition, taxpayers tend to be sceptical and have negative perspectives on taxes. Therefore, the government needs more efforts to raise awareness of tax obligations [24]. Some people are reluctant to pay taxes even when the tax comes in a small amount. No one is completely willing about paying taxes [25]. The role of taxes as a contribution to the country's development is increasingly being ruled out. Many of our informants also considered taxes as a burden. Our first informant, Mr. Ketut, said that: 
“... Taxes depend on our point of view. If we see it from the point of view of profits, taxes are a burden because they are costs we incur to pay. But if we are talking about legality, because we are a legal entity, taxes are considered an obligation."

Mr. Ketut believed that taxes were a form of obligation for his business. It is referred to as a moral obligation [26]. Moral obligation represents a call to one's heart to carry out a dutythe way individuals do the duty of paying taxes are influenced by trust in the tax authorities. Our next informant, Mr. Made, stated the following:

"Taxes are good if they are used properly. Taxes are increasingly being misused nowadays. All entrepreneurs want to pay taxes if the taxes are used properly. Otherwise, we will fulfil these obligations half-heartedly."

It means that tax compliance cannot be separated from the taxpayers' trust in the tax authorities. While it takes a long time to build trust, distrust usually arises quickly. The tax authorities, as the tax collectors, ensure that taxpayers do their obligations - tax compliance increases due to transparency in the use of taxes [27]. Taxpayers' trust in tax authorities is referred to as trust-based compliance [28]. Therefore, tax misuse will lead to decreasing trust and compliance. Corruption also causes a decrease in taxpayers' trust in tax authorities [29].

Tax compliance goes hand in hand with the policies set by tax authorities. Tax payments seem to be simply done to fulfil obligations in the form of legality. Taxpayers pay taxes because the regulation asks them to do so [30]. The difficulty of achieving voluntary tax compliance was also expressed by the third informant, Mrs. Putu. She had tax consultation services to perform both periodic and annual tax reporting. Her responses regarding taxes are as follows:

"The tax authorities do not care whether we have the money or not to pay taxes. They also do not seem to care if we have to pay the debt. The tax authorities only calculate the gross turnover at the tax office. Therefore, I find it difficult to pay taxes."

Mrs. Putu seemed to understand the tax calculation based on Government Regulation Number 23, in which taxpayers can use the calculation on a gross turnover basis or with a general scheme. In this case, the tax consultant should provide directions so that taxpayers can choose the best alternative to do their tax obligations. [31] state that taxpayers must know basic taxation, such as rates and calculations. The self-assessment system is a system for calculating the amount of indebted tax. The correctness of tax calculations becomes the taxpayers' responsibility [32]. [33] argue that taxpayers see tax compliance as a form of coercion from the country. Our first informants confirmed that taxes were seen as a burden, and our second informant added that there was an unwillingness to pay taxes because taxes burdened taxpayers. Our last informant considered taxes as a burden when it came to its complicated calculation.

We concluded from the interview results that they considered taxes a burden, yet they denied it with various reasons to appear as obedient taxpayers. The sincerity of the taxpayers has not accompanied the current tax compliance. It is a form of decline in voluntary tax compliance [34]. The perception of tax as a burden in the form of legality must be changed. It will be difficult to do so, yet it is the right thing to do. The government must help the people no longer see taxes as a burden, especially under the legality perspective, but rather as a form 
of contribution to the country to improve the welfare of the people. Efforts to increase taxes with incentives raise many questions, one of which is the role of these incentives for MSMEs. Therefore, the next section discusses the dynamics of fiscal incentives for MSMEs during the Covid-19 pandemic.

\subsection{The Dynamics of Fiscal Incentives for MSMEs during the Covid-19 Pandemic}

Knowledge about taxes is a problem for the community. With their special role as one of the tax contributors in Indonesia, MSMEs are experiencing problems in taxation. One of the problems faced is the lack of knowledge regarding tax policies. Knowledge about taxes shapes the perception of taxpayers' compliance [35]. Taxpayers who do not understand taxes find it difficult to utilize tax policies, even those whose aim is to reduce tax payable [36]. One form of tax policy to improve tax compliance is fiscal incentives for MSMEs.

The role of fiscal incentives for MSMEs has not been positively accepted. Taxpayers are not actively seeking information on fiscal incentives. During the Covid-19 pandemic, MSMEs focus more on increasing their revenue. [37] argue that MSMEs tend to ignore burdens that do not provide direct benefits. Mr. Made, who utilized fiscal incentives, explained:

"My taxes have been exempted. Now I have to pay taxes again, maybe in January, and now I'm still paying the taxes."

It can be concluded that Mr. Made did not extend the fiscal incentive. In January 2021, the Regulation of the Minister of Finance No. 110/PMK.03/2020 was updated with No.9/PMK.03/2021. Mr. Ketut also experiences the lack of information regarding fiscal incentives reflected in the following interview excerpt:

"From May, we were given tax relief, which means that the government pays taxes, but on the condition that we must apply for it. For now, I'm still receiving the tax relief. For 2021, this relief lasts until June. I get this information from my friends."

Other parties who understand taxes, such as consultants, play a role in the successful implementation of fiscal incentives. [38] argue that tax success starts with good and comprehensive tax socialization. Unfortunately, taxpayers cannot utilize incentives due to the lack of socialization by the tax authorities. In line with that, [39] asserted that lack of socialization led to low awareness of taxpayers fulfilling obligations. In addition, taxpayers do not know that the government provides incentives for MSMEs. Mrs. Putu was one of the MSMEs actors who were not aware of fiscal incentives, as stated in her statement as follows:

"I still pay (taxes). But the (time) of the payment is uncertain. Sometimes it is billed quarterly; sometimes, it is not. During the pandemic, I still paid taxes until last month without incentives."

Mrs. Putu's unawareness caused her to pay taxes as usual. It could be said that the role of her tax consultant was not fully carried out. [40] asserted that tax consultation services were not only helpful in preparing SPT and had a more complex role in providing consultation, training, and socialization. Therefore, consultants play an important role in conveying tax information as a bridge between taxpayers and tax authorities. A good policy is one conveyed well to its users. [41] proved that socialization affects an individual's desire to utilize 
incentives. [42] explained that the interest of taxpayers was in line with the benefits obtained. Therefore, socialization can help increase the implementation of fiscal incentives.

In addition to the lack of socialization, reluctance to utilize tax incentives arises due to administrative factors. There are many complaints from taxpayers regarding tax administration in Indonesia. [43] argued that the simpler the administration, the more aware taxpayers were and the easier it was to implement. Mr. Made experienced the complicated administration as stated in his following statement:

"I never make a report for my taxes myself. I have a tax consultant, the tax consultant told me how to do it, but in the end, they still do it for me. I just do not like doing it myself and then get many questions from the tax authorities. Sometimes, I just feel these authorities are only looking for mistakes in the report. They do not help me to fix mistakes."

It could be inferred that Mr. Made considered tax administration was so complicated. Taxpayers highly expect effective and efficient tax administration. [44] wrote that a good tax administration system was the key to the successful implementation of tax policies. [45] argued that taxpayers would be more obedient if they had a good understanding of tax administration. Mrs. Putu experienced the same thing as Mr. Made:

"Everything is online nowadays. It is no longer complicated because people do not need to queue to pay taxes. It can be a quite long queue sometimes. Taxpayers can now make payments online. However, for taxpayers who do not know how to use it, online payments are complicated, as I experience. I am not sure of what to do. Therefore, my younger sibling asked her friend for help with tax payments, and we only focus on marketing the product."

Mrs. Putu considered that online tax reporting was not difficult but required knowledge in its process. [46] explained that tax administration has not fully implemented the principle of easiness since the enactment of Government Regulation Number 33 of 2018, while [47] stated that it is natural for tax administration to be complicated to obtain accurate evidence of tax compliance. Fiscal incentive administration is carried out online during the pandemic. Socialization on tax administration needs to be done to avoid negative perceptions of tax services. Technology runs fast, while people seem not to have enough understanding of technology. Nowadays, taxpayers need knowledge both in tax and technology.

Mr. Ketut, as a medium enterprise taxpayer, understood fiscal incentives, while small and micro enterprises taxpayers did not. Taxpayers deeply regret the lack of socialization regarding fiscal incentives. Fiscal incentive administration is seen as complicated by those who do not understand tax knowledge. Complicated tax administration was a reason for medium enterprises taxpayers to hire a tax consultant. The role of a tax consultant is to convey tax policies and assist in administration. However, the role of tax consultants for small and micro enterprises is only limited to tax reporting - it could be seen the fact that they did not inform their clients about the fiscal incentives. Therefore, the synergy between taxpayers and consultants needs to be improved to increase the implementation of fiscal incentives. 


\subsection{The Manifestation of Fiscal Incentives for MSMEs}

Another polemic emerges along with the Covid-19 pandemic. MSMEs are experiencing setbacks leading to the turnover decline [48]. We were very interested in examining how turnover decline affected the use of fiscal incentives. Mr. Ketut, one of the informants who understood and utilized fiscal incentives, argued:

"Because I am running a business, I consider tax relief (incentives) as an advantage., It is an obligation for financial statements. So I have to be knowledgeable about it."

Mr. Ketut, as an informant, viewed fiscal incentives as relief in his business. [49] argued that humans as economic beings adhere to economic principles. One of the economic principles is to reduce costs by utilizing government policies, namely fiscal incentives. Mr. Made also made use of fiscal incentives; although he was not familiar with fiscal incentives, he found it helpful:

"Usually, I have to pay taxes, but during the pandemic, people say that I do not have to pay it. Especially during a pandemic, when the economic condition is bad, the incentives give me relief.

We found that fiscal incentives were enough to help MSMEs during the Covid-19 pandemic. Fiscal incentives start to have impacts on the economy. [50] explained that the purpose of incentives was to strengthen the economy and tax compliance. Informants were relieved by fiscal incentives. However, the functions and benefits of the incentives were not conveyed to other informants, Mrs. Putu. During the pandemic, Mrs. Putu had to reduce the number of employees to keep her business running. She did not utilize fiscal incentives due to lack of information, as she stated:

"I do not close my business. But I did some employee termination. In the past, I had 25 employees. I do not understand much about taxes, so I leave everything to the tax consultant. I make decisions based on the tax consultant's suggestion."

Fiscal incentives are used by taxpayers who understand taxes well. All MSMEs very much need tax socialization. Although taxpayers feel the positive impact of fiscal incentives, the economic strengthening has not been fully reached through incentives. It was reflected in the perspectives of taxpayers who regretted the lack of information on fiscal incentives. Acceleration of the national economy will be difficult if the actors do not know the existing policies. Therefore, tax socialization for the community is very important.

We found that the micro and small enterprises taxpayers rarely utilized the incentives due to some reason. Their perception was only to pay the tax in small amounts because their revenue decreased drastically due to the pandemic. The medium enterprise taxpayers hired tax consultants due to complicated tax administration. Their perception was to pay the tax based on the tax consultants' advice, and they appreciated any incentives given. Tax authorities and taxpayers, who slowly realize the importance of taxes, play a role in continuing fiscal incentives. Fiscal incentives implemented to the whole community, especially MSMEs, must reduce the economic burden instead of adding complexity amid a pandemic. 


\section{Conclusions}

The non-formal MSMEs sector is most affected by the pandemic. Taxpayers, in this case, MSMEs, cannot do much to help reduce the pandemic's effect. Economic improvement seems hard to achieve. The government helps MSMEs by launching a fiscal incentive policy. Findings confirmed that micro-enterprises rarely utilized fiscal incentives, like Mrs. Putu. The lack of understanding of taxpayers led to the low utilization of government assistance.

The low use of fiscal incentives by MSMEs occurred because of a lack of tax knowledge and complicated administration. Taxpayers were reluctant to understand taxation because it seemed complicated, as experienced by Mr. Made. Taxpayers perceived that they only had to pay a small amount of tax due to the drastic revenue decline during the Covid-19 pandemic. Mr. Made chose to pay taxes as usual to avoid administrative problems and complexity. The main reason was that taxpayers were not accustomed to using technology in taxation activities. Therefore, the role of consultants is needed.

The new policy set by the government was only known by some people with a good tax knowledge, such as tax consultants. It was why the medium enterprises actor, Mr. Ketut, used the service of tax consultants. Medium enterprise taxpayers paid the tax based on the tax consultants' advice, and they appreciated any incentives given. Unfortunately, they did no have adequate knowledge on technology amid the advance development of technology.

Taxpayers expect online-based tax policies, like reporting and fiscal incentives, to be more effective to increase tax compliance.

\section{References}

[1] F. R. Yamali and R. N. Putri, "Dampak Pandemi Covid-19 Terhadap Ekonomi Indonesia," Ekon. J. Econ. Bus., vol. 4, no. 2, pp. 384-388, 2020.

[2] R. R. Bahtiar and J. P. Saragih, "Dampak Covid-19 Terhadap Perlambatan Ekonomi Sektor UMKM," J. Bid. Ekon. dan Kebijak. Publik, vol. 12, no. 6, pp. 19-24, 2020.

[3] M. Indaryani, N. A. Budiman, and S. Mulyani, "Dampak Covid-19 dan Pemanfaatan Insentif Pajak terhadap Keberlangsungan Usaha pada UMKM Tenun Troso Jepara," $J$. Manaj. dan Keuang., vol. 9, no. 3, pp. 276-285, 2020.

[4] K. N. Ihza, "Dampak Covid-19 Terhadap Usaha Mikro, Kecil, dan Menengah (UMKM) (Studi Kasus UMKM Ikhwa Comp Desa Watesprojo, Kemlagi, Mojokerto),” J. Inov. Penelit., vol. 1, no. 7, pp. 132-133, 2020.

[5] C. Adi Kurnia, "Dampak Pandemi Covid-19 Dan Perubahan Pola Administrasi Terhadap Pelaku Umkm Ekspor Dan Impor,” Al-Ijtima i Int. J. Gov. Soc. Sci., vol. 6, no. 1, pp. 1-12, Oct. 2020, doi: 10.22373/jai.v6i1.607.

[6] Silpa Hanoatubun, "Dampak Covid-19 Terhadap Perekonomian Indonesia," J. Educ. Psychol. Couns., vol. 2, no. 1, pp. 146-153, 2020.

[7] K. K. R. Indonesia, Peraturan Menteri Keuangan Republik Indonesia Nomor 9/PMK.03/2021 Tentang Insentif Pajak Terdampak Pandemi Corona Virus Disease 2019. 2021.

[8] L. Marlina and S. Syahribulan, "Peranan Insentif Pajak Yang Di Tanggung Pemerintah (DTP) Di Era Pandemi Covid 19," Econ. Depos. J., vol. 2, no. 2, pp. 13-15, 2021, doi: 10.36090/e-dj.v2i2.910.

[9] Direktorat Jendral Pajak, "Rasio Pajak Dari Masa Ke Masa,” Djp, 2020. .

[10] D. S. P. Astuti, "Ekonomi di Masa Pandemi Covid-19," Suara Merdeka, 2020. 
[11] H. Mudiarti and U. R. Mulyani, "Pengaruh Sosialisasi Dan Pemahaman Peraturan Kemauan Menjalankan Kewajiban Perpajakan Pada Masa Covid-19 ( Pada Umkm Orang Pribadi Sektor,” Account. Glob. J., vol. 4, no. 6, pp. 167-182, 2020.

[12] N. D. Kartiko, "Insentif pajak dalam merespons dampak pandemi covid-19 pada sektor pariwisata," J. Pajak Dan Keuang. Negara, vol. 2, no. 2, p. 124, 2020.

[13] D. A. N. Dwi Ariyanto, "Pengaruh Persepsi Tarif Pajak Terhadap Kepatuhan Wajib Pajak UMKM," AKUNESA J. Akunt. Unesa, vol. 8, no. 3, pp. 58-60, 2020.

[14] F. M. Ropinov Saputro, "Pengaruh Tingkat Pendidikan Pemilik, Praktik Akuntansi Dan Persepsi Atas Insentif Pajak Terhadap Kepatuhan Pajak Umkm," J. EMBA J. Ris. Ekon. Manajemen, Bisnis dan Akunt., vol. 8, no. 4, pp. 101-102, 2020, doi: 10.35794/emba.v8i4.31308.

[15] P. Octavianny, M. Makaryanawati, and F. M. Edwy, "Religiusitas, Kepercayaan pada Aparat, Tingkat Pendidikan, Pengetahuan Perpajakan dan Kepatuhan Wajib Pajak," EJurnal Akunt., vol. 31, no. 1, pp. 88-91, 2021, doi: 10.24843/eja.2021.v31.i01.p06.

[16] A. Junaidi, "Strategi Bisnis Dan Pemanfaatan Kebijakan Pajak Di Masa Pandemi Covid-19 Dan Era New Normal (Studi Kasus Pelaku UKM Marketplace)," J. Chem. Inf. Model., vol. 21, no. 1, pp. 1-9, 2020.

[17] S. N. Sarfiah, H. E. Atmaja, and D. M. Verawati, "UMKM Sebagai Pilar Membangun Ekonomi Bangsa," J. Ris. Ekon. Pembang., vol. 14, no. 2, p. 18, 2019.

[18] D. A. Putra, "UMKM Sumbang 60 Persen ke Pertumbuhan Ekonomi Nasional," Merdeka.com, 2018. .

[19] Badan Pusat Statistik (BPS), "Pendapatan Nasional (National Income of Indonesia)," Buku Publ. Stat., vol. 1, no. 1, 2020.

[20] Direktorat Jenderal Pajak (DJP), "Lampaui Target Penerimaan, Badung Utara Beri Apresiasi Wajib Pajak," 2020.

[21] A. K. Hua, "Pengenalan Rangkakerja Metodologi dalam Kajian Penyelidikan: Satu Kajian Kes,” J. Soc. Sci. Humanit., pp. 17-23, 2016.

[22] K. T. Kustina and N. L. P. S. A. Dewi, "Analisis Kemitraan Bank Dan Koperasi Dalam Bentuk Layanan Branchless Banking Untuk Meningkatkan Pendapatan Koperasi," Account. Prof. J., vol. 1, no. 1, p. 80, 2019, doi: 10.35593/apaji.v1i1.12.

[23] L. Listiyowati, I. Indarti, F. Wijayanti, and F. A. Setiawan, "Kepatuhan Wajib Pajak UMKM di Masa Pandemi COVID-19," J. Akunt. Indones., vol. 10, no. 1, pp. 41-59, 2021, [Online]. Available: https://doaj.org/article/1bb76cf0b5b345a2bce6a7e004524471.

[24] P. A. K. P. Suardana, Putu Ayuni Kartika Putri, Suardana, "Menakar Skeptisisme Dalam Membayar Pajak Ditinjau Dari Perspektif Wajib Pajak," J. Penelit. Teor. Terap. Akunt., vol. 6, no. 1, pp. 117-121, 2021, doi: 10.51289/peta.v6i1.470.

[25] I. N. Darmayasa, Y. R. Aneswari, and E. E. Yusdita, "Meningkatkan Kepatuhan Dan Penerimaan Pajak Melalui Withholding Tax System," InFestasi, vol. 12, no. 2, 2017, doi: 10.21107/infestasi.v12i2.2769.

[26] Z. D. Nabila and I. Isroah, "Pengaruh Kewajiban Moral Dan Lingkungan Sosial Terhadap Kepatuhan Wajib Pajak Orang Pribadi Pengusaha," Nominal Barom. Ris. Akunt. dan Manaj., vol. 8, no. 1, pp. 192-193, 2019, doi: 10.21831/nominal.v8i1.24498.

[27] M. Rahma, "Transparansi Pajak dan Kepercayaan Wajib Pajak Terhadap Kepatuhan Wajib Pajak (Survei padaWajib Pajak Kota DKI Jakarta),” J. Akunt., vol. 4, no. 1, pp. 34-35, 2019.

[28] M. Y. Mahadianto and A. D. Astuti, "Previllage Tax Payer, Sosialisasi Pajak Dan 
Kepercayaan Pada Otoritas Pajak Terhadap Kepatuhan,” J. Kaji. Akunt., vol. 1, no. 1, pp. 45-47, 2017, doi: 10.33603/jka.v1i1.525.

[29] A. Purnamasari, U. Pratiwi, and S. Sukirman, "Tingkat Kepercayaan Pada Pemerintah Dan Hukum, Serta Nasionalisme Terhadap 22 Kepatuhan Wajib Pajak Dalam Membayar Pbb-P2 (Studi Pada Wajib Pajak PBB-P2 Di Kota Banjar)," J. Akunt. dan Audit., vol. 14, no. 1, pp. 22-39, 2018, doi: 10.14710/jaa.v14i1.18221.

[30] F. Handayani, B. Bachtiar, and N. Khomariah, "Faktor-Faktor yang Mempengaruhi Kepatuhan Wajib Pajak UMKM di Kecamatan Balikpapan Kota,” J. Ilm. Akunt. dan Keuang., vol. 9, no. 1, pp. 53-60, 2020, doi: 10.32639/jiak.v9i1.338.

[31] S. Saryadi and R. J. Pinem, "Sosialisasi Perhitungan Dan Pelaporan Wajib Pajak Usaha Mikro, Kecil Dan Menengah (UMKM) Kota Semarang," CARADDE J. Pengabdi. Kpd. Masy., vol. 2, no. 1, pp. 136-137, 2019, doi: 10.31960/caradde.v2i1.95.

[32] A. N. Prasetyarini, O. Rusmana, and N. K. Putri, "The Effectiveness Of SelfAssessment System on Tax Revenue," Acta Univ. Danubius, vol. 15, no. 4, pp. 34-39, 2019.

[33] E. E. Y. Yuyung Rizka Aneswari, I Nyoman Darmayasa, "Perspektif Kritis Penerapan Pajak Penghasilan 1\% pada UMKM,"Simp. Nas. Perpajak., vol. 5, 2020.

[34] F. Inasius, G. Darijanto, E. Gani, and G. Soepriyanto, "Tax Compliance After the Implementation of Tax Amnesty in Indonesia," SAGE Open, vol. 10, no. 4, pp. 177178, 2020, DOI: 10.1177/2158244020968793.

[35] R. Indrawan and B. Binekas, "Pengaruh Pemahaman Pajak dan Pengetahuan Pajak Terhadap Kepatuhan Wajib Pajak UMKM,” J. Ris. Akunt. dan Keuang., vol. 6, no. 3, pp. 419-428, 2018, doi: 10.17509/jrak.v6i3.14421.

[36] Y. Mangoting, Christopher, N. Kriwangko, and W. Adriyani, "Interaksi Komitmen Dalam Dinamika Kepatuhan Pajak,” J. Akunt. Multiparadigma, vol. 11, no. 2, pp. 265277, 2020, doi: 10.21776/ub.jamal.2020.11.2.16.

[37] L. Setiawati and J. K. Tjahjono, "Pengaruh Penerapan Peraturan Pemerintah No. 46 Tentang PPH Final Terhadap Pajak Penghasilan Dan Profit PT.X,” J. GEMA Aktual., vol. 4, no. 1, pp. 162-165, 2015.

[38] D. K. Wardani and E. Wati, "Pengaruh Sosialisasi Perpajakan Terhadap Kepatuhan Wajib Pajak Dengan Pengetahuan Perpajakan Sebagai Variabel Intervening (Studi Pada Wajib Pajak Orang Pribadi di KPP Pratama Kebumen)," Nominal, Barom. Ris. Akunt. dan Manaj., vol. 7, no. 1, pp. 28-50, 2018, doi: 10.21831/nominal.v7i1.19358.

[39] H. A. Y. Sari, M. Makaryanawati, and F. M. Edwy, "Pengaruh Sosialisasi Pajak Terhadap Realisasi Penerimaan Pajak dengan Kepatuhan Wajib Pajak Sebagai Variabel Intervening," Own. (Riset dan J. Akuntansi), vol. 4, no. 2, pp. 65-67, 2020, doi: 10.33395/owner.v4i2.289.

[40] D. Khairannisa and Charoline Cheisviyanny, "Analisis Peranan Konsultan Pajak Terhadap Kepatuhan Wajib Pajak Dalam Memenuhi Kewajiban Perpajakan,” $J$. Eksplor. Akunt., vol. 1, no. 3, pp. 1151-1167, 2019, [Online]. Available: http://jea.ppj.unp.ac.id/index.php/jea/article/view/133.

[41] H. Triatmoko, J. Juliati, S. Suranta, T. R. Wulandari, and R. Zoraifi, "Persepsi Wajib Pajak UMKM Terhadap Kewajiban Perpajakan (Studi Pada UMKM di Eks Karisidenan Surakarta)," J. Akunt. dan Pajak, vol. 21, no. 02, pp. 186-187, Jan. 2021, doi: 10.29040/jap.v21i02.1537.

[42] S. Latief, Junaidin Zakaria, and Mapparenta, "Pengaruh Kepercayaan Kepada Pemerintah, Kebijakan Insentif Pajak dan Manfaat Pajak Terhadap Kepatuhan Wajib Pajak," Cent. Econ. Student J., vol. 3, no. 3, pp. 72-73, 2020. 
[43] R. Amalia Fajar, "Pengaruh Modernisasi Sistem Administrasi Perpajakan Terhadap Tingkat Kepatuhan Pengusaha Kena Pajak Di KPP Pratama Makassar Selatan," Hasanuddin Univ. Repos., pp. 20-22, 2017.

[44] HP Monalika, "Pengaruh reformasi administrasi perpajakan terhadap kepatuhan wajib pajak: Studi kasus di KPP Pratama Kedaton Bandar Lampung,” J. Akunt. Keuang. dan Manaj., vol. 1, no. 2, pp. 158-161, 2020, doi: 10.35912/jakman.v1i2.13.

[45] C. Polii and J. Sondakh, "Pengaruh Modernisasi Administrasi Perpajakan Terhadap Kinerja Kantor Pelayanan Pajak Pratama Kotamobagu," J. EMBA J. Ris. Ekon. Manajemen, Bisnis dan Akunt., vol. 5, no. 2, pp. 128-130, 2017, doi: 10.35794/emba.v5i2.16477.

[46] D. Lesmana, D. Panjaitan, and M. Maimunah, "Pengaruh Modernisasi Sistem Administrasi Perpajakan, Dan Sanksi Pajak Terhadap Kepatuhan Wajib Pajak Umkm Di Kota Palembang," J. Akunt., vol. 5, no. 1, pp. 22-32, 2018, doi: 10.5281/zenodo.1479252.

[47] S. Pricilia, "Analisis Faktor-Faktor yang Mempengaruhi Persepsi Wajib Pajak Orang Pribadi Untuk Minat Menggunakan E-Filing,” J. Akunt. Univ. Negeri Semarang, vol. 6, no. 1, pp. 89-93, 2016.

[48] B. M. Muhammad and A. Wirjolukito, "Evaluasi Kepatuhan Pajak Berdasarkan Perilaku Data Keuangan dan Non Keuangan (Studi Kasus pada KPP Jakarta), EJurnal Akunt., vol. 31, no. 1, pp. 116-129, 2021, doi: 10.24843/EJA.2021.v31.i01.p09.

[49] J. Takahata, T. Dartanto, and K. Khoirunurrofik, "Intergovernmental Transfers in Indonesia: The Risk Sharing Effect of Dana Alokasi Umum.," J. Southeast Asian Econ., vol. 38, no. 1, pp. 81-99, 2021, DOI: 10.1355/ae38-id.

[50] R. R. Sitorus, "Moderasi Insentif Pajak Di Era Pandemi Covid-19 atas Pengaruh EFaktur Dan E-Bukti Potong Terhadap Kepatuhan Wajib Pajak," J. Bus. Stud., vol. 5, no. 2, pp. 145-147, 2020. 